\title{
The Pendulum is never static: Jesus Sira to Jesus Christ on Women in THE LIGHT OF Judith, SusanNa AND LXX Esther
}

Author:

Pierre Jordaan ${ }^{1}$

\section{Affiliation:}

${ }^{1}$ Biblical Studies and

Ancient Languages,

North-West University,

South Africa

\section{Correspondence to:}

Pierre Jordaan

e-mail:

pierre.jordaan@nwu.ac.za

\section{Postal address:}

Biblical Studies and

Ancient Languages,

North-West University,

Potchefstroom Campus,

Private Bag X6001, South

Africa

\section{Keywords:}

New Testament; Jesus

Sira; Judith; Susanna; LXX

Esther

\section{Dates:}

Received: 04 Apr. 2009

Accepted: 17 Apr. 2009

Published: 03 Aug. 2009

How to cite this article: Jordaan, P., 2009, 'The pendulum is never static: Jesus Sira to Jesus Christ on women in the light of Judith, Susanna and LXX Esther', HTS Teologiese Studies/Theological Studies 65(1), Art. \#167, 6 pages.

DOI: $10.4102 /$ hts.v65i1.167

This article is available at: http://www.hts.org.za

\section{(c) 2009. The Authors.} Licensee: OpenJournals Publishing. This work is licensed under the Creative Commons Attribution License.

\section{ABSTRACT}

When the New Testament is interpreted, directly preceding literature is largely neglected. The dialectical terms, discourse and contra-discourse do not often surface in research on this period. This is especially the case with reference to women. Jesus Ben Sira (ca. 196 BCE) as well as other wisdom writers had quite a negative view of women. Although it has previously been argued that this negative discourse on women was challenged by Judith, this article goes further: the Additions to Esther and Susanna are added as possible challenging discourses. It is argued that these texts convincingly confront Ben Sira's negative views and add substantial value to the worth and status of women. During the CE, both Jesus Christ and the Apostle Paul had a mainly positive view of women. Positive ideas and allusions from texts are pointed out that might have their roots in the Apocrypha. Lastly, this article argues that the disputed Pauline letters contain a swing back towards Jesus Ben Sira's negative view of women.

\section{INTRODUCTION: PROBLEM STATEMENT}

Until recently, the apocryphal books of the Old Testament in the time frame from 200 BCE to the $\mathrm{CE}$ - also referred to as the so-called Deutero Canonical Books of the Old Testament - had largely been discarded in the interpretation of the New Testament. One reason for this state of affairs was purely pragmatic: there are no direct quotes from these books in the New Testament (DeSilva 2002:21). Another reason was dogmatic prejudice. These books were excluded from the so-called inspired canonical scriptures - in the reformed tradition - and were therefore deemed unworthy of dogma and proclamation (Kaiser 2004:6). They could be used for teaching - as the Belgic Confession states - but this rarely, if at all, happened in a reformed congregation.

However, a few factors have contributed to a renewed appreciation of the Old Testament Apocrypha:

The first factor has been the recognition that the New Testament writings have certain predecessors that cannot be discounted. The New Testament is the product of - as Charlesworth (1985:85) put it a long historical and linguistic process. This might include pseudepigraphic as well as apocryphal documents. Written by Charlesworth more than 20 years ago, this was an important acknowledgement of the possible background to any given New Testament text.

The second factor has been the immense development within literary science and literary philosophy: new insights - especially regarding the generation of texts - have come to the fore. Ancient texts were no longer seen as merely autonomous documents; intertextuality (Gruen 1998:294) and contratexts (Epston \& White 1990:18-29) became buzz-words in the research of the genesis of texts. Various options were considered: texts from the Deuteronomistic and Chronistic History (Aune 1989:98-101), the Greco-Roman world (Malherbe 1986) and the Dead Sea scrolls (Nickelsburg 2005:119-189) were seen as possible pre-texts for the New Testament.

The above-mentioned research of possible preceding texts has, however, overstepped the requirement of direct textual evidence. It always seemed to be safest if there was a one-to-one correlation between two texts involved (Charlesworth 1985:71). However, it has now been recognised that one text might also be an allusion of another text.

According to the Oxford Advanced Learner's Dictionary (2005:39), 'allusion' means 'something that is said or written that refers to or mentions another person or subject in an indirect way'. Such allusion or indirect reference to another person or subject might be positive (affirming) or negative (contradicting). The possibility of allusion has opened up a wide interpretation of the New Testament in relation to its possible predecessors. This suggests that different writings in the New Testament and New Testament Umwelt might have been created either to contradict or to complement each other.

Ironically enough, a substantial amount of work within the New Testament itself has already been done this way. Books that complement each other are typically the Johanine corpus of books (Burkett 2002:453). A few contradictory books have also, however, been pointed out:

- As far back as 1831, F.C. Bauer and the Tübingen School (Bruce 1979:42) stated that there was substantial conflict not just within the Pauline epistles of Galatians and Corinthians but also between the apostles Paul and Peter. Peter maintained a judaising version of Christianity while Paul insisted that the gospel involved the abolition of Jewish legalism and particularism.

- Mussner (1967:152-207) mentioned the possibility that James's emphasis on works might be a reaction to Paul's emphasis on faith.

- In the Old Testament, the inclusion of the Moabitess Ruth in the Book of Ruth was considered by scholars like Van Maanen (1954:60) as a contra-narrative against the sending away of other women in Ezra-Nehemiah. 
The scope of this article is in line with these possibilities, the hypothesis being that Judith, the Additions to Esther and Susanna were written as a reaction against the negative view on women by Jesus Ben Sira and his associates. This positive reaction was embraced by both Paul and Jesus. However, it seems that in the later, disputed Pauline epistles, there was a swing back towards the negative view of women, hence part of the title of this article Jesus Sira to Jesus Christ on women in the light of Judith, Susanna and LXX Esther.

The study on which this article was based was undertaken in the following way:

- An excursion of Jesus Ben Sira's and his associates' views on women

- An excursion of Judith's views on women

- An excursion of the Additions to Esther and its views on women

- An excursion of Susanna's views on women

- A point of departure concerning New Testament literature

- A possible allusion to the Old Testament Apocrypha by Paul on women

- A possible allusion to the Old Testament Apocrypha by Jesus on women

- A brief excursion of the latter disputed Pauline epistles on women

- A conclusion.

Since this study involved the study of literature in a dialectic system, recourse to Michael Foucault was essential. The uniqueness of Foucault's contribution to the interpretation of texts has lain in the relation that he has found between texts. This usually forms pro and contra-indications for a specific viewpoint. Foucault's angle has accurately been depicted as 'the attempt to rediscover the interaction of discourses as weapons of attack and defence in the relation of power and knowledge' (Sarup 1989:73).

The issue under investigation has exactly been that, namely the different discourses that were used within the Old Testament Apocrypha either to exclude or to include certain groups, in this instance, women. This investigation furthermore deals with how these discourses might have been taken up in the New Testament.

\section{JESUS BEN SIRA ON WOMEN}

Jesus Ben Sira was a famous Jewish wisdom teacher who wrote the book known by his name between 196 and 175 BCE (Nickelsburg 2005:62). Like other writers of wisdom literature - Proverbs and Ecclesiastes - he provided advice for life. His writings were mainly practical instructions to 'young men' (Collins 1999:88) on certain important moral issues, including behaviour towards women. About women, however - like other wisdom writers - he was negative (see section 'Women as Bad Wives')

\section{Women in the Wisdom of Ben Sira}

The Wisdom of Jesus Ben Sira deals with women in five categories, according to Trenchard (1982), namely women as good wives, as mothers and widows, as bad wives, as adulteresses and whores and, lastly, as daughters.

Women as Good Wives (7:19, 26a; 9:1-9; 25:1, 8a; 26:1-4, $13-18 ; 28: 15 ; 36: 21-26 ; 40: 19,23)$

Although Ben Sira was negative towards women, he often praised good wives. In his view, however, a woman's goodness was defined in relation to her husband. He pointed out some criteria that made a good wife: a wife could be regarded as good

1.Sections 'Jesus Ben Sira on women' and 'The view of women in Judith, Esther and Susanna' contain a rewritten, extended work by Jordaan and Kanonge (2006). when she met her husband's needs, made him happy, caused him to be respected in society, pleased him sexually, remained silent and looked beautiful. In short, a good wife had no independence outside of her husband (Trenchard 1982:38). This also seems to have been the view of a good wife in Proverbs 31:10 to 31; a wife was good only when she did all the tasks at home and enabled her husband to sit and talk to the elders at the city gates.

Women as Mothers and Widows $(3: 4,9,16 ; 4: 10 ; 7: 27-28$; 15:2; 23:14; 35:14-15; 41:17a)

Ben Sira spoke of mothers from the perspective of a patriarchal society. He saw no way that a child could be with her or his mother without a father; his mention of a mother was always beside a father and the father always preceded the mother. Ben Sira used one adjective to describe widows, and that was 'poor'. He defined the worth of both mothers and widows here in terms of the husband. The husband was the constituting factor that determined qualitative parenthood and the living standard for widows. His view on mothers and widows was that they had to conform to the view of his society (Trenchard 1982:56).

Women as Bad Wives $(7: 26 ; 9: 2 ; 25: 13-26 ; 26: 5-9 ; 33: 20$; $37: 11 ; 42: 6 ; 47: 19)$

In this section, Ben Sira talked about women and gave advice on women. If a man had a wife he did not like, why keep her

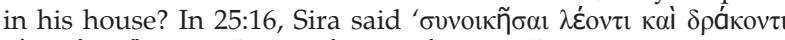

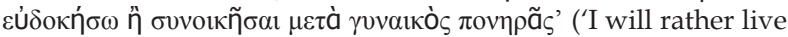
with a lion or dragon than live with a bad wife.')

Ben Sira here had the same view as Proverbs $(2: 16-17 ; 6: 26-7: 24$; 9:13-15; 11:16, 22; 12:4; 14:1; 19:13-14; 21:19; 23:26-27; 25:24; 30:20; 31:10) and Ecclesiastes (7:28).

\section{Women as Adulteresses and Whores $(9: 8-9 ; 19: 2-3$; $23: 22-26 ; 26: 9 ; 41: 20-22 ; 42: 8)$}

To Ben Sira, women and wine were alike (Ben Sira 19:2) because they could make a man lose all self-control and cause him to slide into disaster. Men going to prostitutes would end up in shame and lose their life. It was thus degrading to men. Ben Sira had no word for a male prostitute; it could only be a woman.

\section{Women as Daughters (7:24-25; 9:5; 22:3-5; 26:10-12; 42:9-14)}

Ben Sira made his most negative statements against women when he spoke about daughters. In Sira 22:3, he stated that

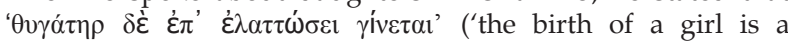

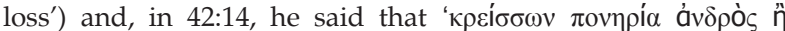

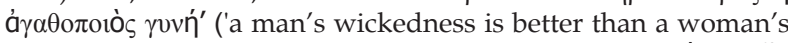
goodness'). About her sexuality, he said, in 26:12, that ' $\dot{\omega} \varsigma \delta i \psi \tilde{\omega} v$

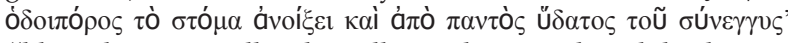
('like a thirsty traveller she will open her mouth and drink any water she comes across')

By this, he meant that a girl would enjoy sexual relations with anyone. Reading these passages on daughters, we can conclude that, for Ben Sira:

Daughters are less significant and more troublesome than sons, married or unmarried, girls represent a real or potential economic burden to their fathers, they are often the source of anxiety and shame to their fathers, require special monitoring by their fathers, are to be kept as marriageable as possible or to be kept from divorce, (and) are sexually irresponsible.

(Trenchard 1982:167)

Ben Sira's view of women was thus mainly negative. A woman was good when she lived for her husband. Women were a potential danger because of their sexuality. Married or unmarried, daughters were useless and troublesome to their fathers; they were a burden and needed to be watched constantly. Although Ben Sira seemed to go too far in his view of women, his ideas were largely shared by fellow wisdom writers in both Proverbs and Ecclesiastes. 


\section{VIEW OF WOMEN IN JUDITH, ESTHER AND SUSANNA}

The views of Ben Sira are now challenged through a different discourse, namely that of Judith ${ }^{2}$, the Additions to Esther and the Additions to Daniel: Susanna.

\section{Judith}

The book of Judith, Iov $\delta 1 \theta$ (a Jewish woman), in Greek is a story of a widow heroine who delivered her people. This book was probably written in the Hasmonean state around 107 BCE (DeSilva 2002:92). It is a narrative in two parts. The first part describes a crisis facing Israel due to the ambitious plan of Nebuchadnezzar to control the entire world (1-7). Israel lacks courage and urges its leaders to surrender. This part emphasises the weakness of men's leadership because of their lack of faith in and knowledge of God. The second part of the narrative elaborates on the intervention by Judith. Since the first part serves as the reason for Judith's intervention, focus here is on the second part.

\section{Judith and the Elders (Judith 8:1-35)}

In an ironic, sarcastic and hyperbolic style, the author depicts the difference between Judith and the men:

\section{JUDITH}

\section{She has authority.}

She has knowledge of God and the historical traditions of Israel.

She has faith and commitment, embodied in her communion with God by prayer and observance of the law.

She has courage, zeal and the determination to defend the case of God even to the cost of her life.

She is competent and willing to act in a desperate situation.
THE ELDERS

They display distressing weakness They are ignorant of God and his almightiness.

They are interested in enjoyment and parties.

They are lax and show an urge to surrender.

They are incompetent and unwilling to act in a desperate situation.
This is exactly the opposite of what Ben Sira said about women in the case of Judith, a widow. This discourse challenged Ben Sira's views on women and triumphed over them. It should be mentioned that the first part (Chapter 5:21-6:13) also introduces a male character, namely Achior, an Ammonite hireling. According to Dn 23:3, the Ammonites, together with the Moabites, were the cursed nations that were forbidden to enter the temple. Achior warned general Holofernes that his army would not succeed against the Israelites; he said to Holofernes, in 5:21, to

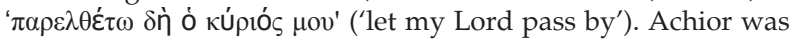
subsequently mocked and excommunicated to Bethulia, where he was accepted and comforted by the Israelites.

\section{Judith takes action to save Israel (Judith 9:1-10:8)}

Before Judith took action, she first prayed. There was no penitential prayer and women were prominent in the prayer. In Judith 9:2, there is direct reference to the rape of Dinah and the vengeance of her brothers (Simeon and Levi) as it is described in Genesis 34. Although Jacob disapproved of the action, Judith recognised in it the initiative of God to punish those who had defiled Dinah, a representative of God's people. Judith's point was that any attempt to destroy or defile God's people had to be avenged in any way. To champion his cause, God always chose someone who was ready. Gender was irrelevant, for victory belonged to God. Judith further wailed in 9:4 that daughters were being carried off and again referred to gender as she urged

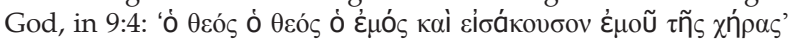
('O God, my God, hear this widow too.')

2.Alexander Di Lella (1996), in the article Women in the Wisdom of Ben Sira and the Book of Judith: A study in contrasts and reversals, used only Judith to show a contra-narrative. This article, however, goes further and includes the Additions to Esther and Susanna.
Judith overcomes Holofernes (10:9-13:10a)

This is the heart of the story - dramatic, like a Greek novel and captures the attention of the reader. Judith's entrance into the Assyrian camp was perceived as a big event because she did what no man would do; she simply walked into the camp of the enemy. Her beauty fascinated all men; it seems that the Assyrian soldiers lost their minds when they saw her. They assumed ironically - that it was dangerous for a nation to have women like this (Judith 10:19), for her beauty would make other men kill for her, thereby endangering themselves.

Holofernes was the idiotic man who walked into the trap. He fulfilled the role of pars pro toto; he stood for the entire Assyrian army. In 11: 6, Judith became his military strategic advisor - and

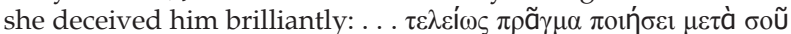

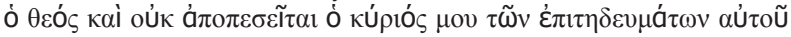
('My God will do his business perfectly with you. And my Lord will not fail in his business.') (Judith 11:6).

Holofernes mistakenly thought that 'my Lord' referred to him; instead, it referred to Judith's lord - God. Holofernes thought that victory was already his - but he was being deceived all the while. Ultimately, Judith killed him by cutting off his head.

By way of analogy, the story of Judith was reminiscent of all Jewish heroines, such as Miriam (Exodus 15:20-21), Deborah, Jael (Judges 4-5), the woman of Thebez (Judges 9:53-54) and the woman of Abel Beth Maacah (2 Samuel 20:14-22). With this in mind, the author necessarily had a gender issue in view while writing. The killing of Holofernes also paralleled David and Goliath. It is clear that the author placed Judith in the same line as other male heroes of Israel's history. Achior, the Ammonite who was still with the Israelites, now believed, whereupon he was circumcised and accepted into the house of Israel:



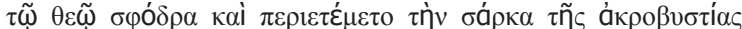

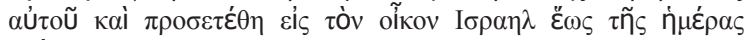

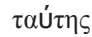

('When Achior saw everything that the God of Israel did, he believed in God greatly and he was circumcised on the flesh of his foreskin and was joined to the house of Israel to this day.')

(Judith 14:10)

\section{The rest of the novel}

Judith was an extraordinary woman. After her husband's death, she managed their business both without restraint and independently, she was wealthy and she had male as well as female servants (Judith 8:7). Judith, on her own, was in charge of a whole household and a business - contrary to the subservient woman of Proverbs 31. Judith's manager was also a woman (Judith 8:10), she freed her slave before her death (Judith 16:23) and she shared her wealth with her own family and her husband's family (Judith 16:24). The consideration that Judith enjoyed after her victory surpassed that of most biblical heroes. She was hailed as follows with the glory of the nation:

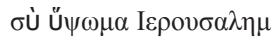

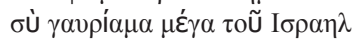

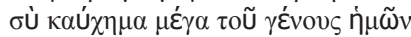

('You are the glory of Jerusalem!

You are the great pride of Israel!

You are the highest honour of our race.')

(Judith 15:9)

To summarise: The book Judith challenged the status quo in various areas. The most prominent area was to show, in contrast with Jesus Ben Sira, the worth of women. Another area was in contrast to the social order regarding the inclusion of other people, like the Ammonites. A last area concerned the emancipation of slaves (Leviticus 25:46) and the inheritance by a widower's family. Although this might have happened in Israel, it was not the rule - it was the exception. 


\section{Additions to Esther}

This book, also known as the Additions to Greek Esther, embodies six parts, named A, B, C, D, E and F. The final form of the text (all six additions) is accepted as done by Jerome, namely added separately at the end (Nickelsburg 2005:202). It is also accepted among scholars (Gruen 1998:178; Moore 1985:203) that the final date of the composition of the Additions to Esther was about 100 BCE. For our argument, as with Judith, it is important that the final form of the text is placed after Ben Sira. Like Judith, these Additions describe Israel facing an apocalyptic genocide that only Esther was able to stop on the strength of her position. It is a typical palace story, like that of Joseph in Egypt, except that it is a woman - not a man - who is the protagonist (Gruen 1998:108, 296)

\section{Prayer and intervention (C and D)}

During the Second Temple period (536 BCE to $70 \mathrm{CE}$ ), penitential prayers became an institution for Jews. Because there were no more sacrifices or priests' interventions, private worship rose from every private room. A penitential prayer was usually a prayer by an individual on behalf of a whole group (Boda, Falk \& Werline 2006:xvi). This was exactly what Esther eventually undertook, although there was a difference. Esther felt the need to confess her 'personal sins' first. Esther felt guilty about her sexual relationship with the king. She compared her crown to a menstrual rug; Kottsieper (1998:175) has stated that, by comparing the crown to a menstrual rug, Esther wanted to denote the obligatory nature of her circumstances. She had no choice, just as a woman had no choice but to be regarded as unclean during her monthly cycle and to have to wear a menstrual rug. She also had to wear a foreign nation's crown. The difficult position that she was in was for a greater aim.

Esther's personal confessions give an idea about the fact that she was willing to suffer bodily indignity for the sake of her nation. She further confessed that she had never eaten at Haman's table or enjoyed royal drinking parties, thereby revealing her antisocial behaviour. After her prayer, Esther ventured to see the king without being invited (Addition D). Addition D is a vivid, colourful scene. According to Day (1995:215) and Fox (1991:272), this not a typical Jewish picture being painted here. Day is of the opinion that it rather has roots in the Greek novel, where women were usually the protagonists, with little real power over their environments, even though they were well educated. Female characters in these novels were usually young and attractive and the victims of forces beyond their control. The Jewish reader in the Diaspora, having been exposed to the Hellenistic culture, would certainly have been impressed by this representation of a Jewish queen (Jordaan 2006:56).

Esther's audience with the king is the turning point in the story (Harvey 2003:230). Well dressed, with her two servants, Esther set out. Beautiful but trembling, she passed the gate, the point of no return. God, however, entered the scene to soften king Artaxerxes's heart (Kottsieper 1998:184). Esther said nothing but she fainted twice. The king reassured her, however, that she was not a mere commoner but royalty and thus had a different set of rules that she had to adhere to.

Queen Esther was clearly overstepping the boundaries. Like Judith, however, she had the courage to challenge the enemy (Day 1995:222). Mordecai, who was serving in the king's palace, could have done the same. He did not; Esther was the one who took action.

\section{The dream and its interpretation ( $\mathrm{A}$ and $\mathrm{F}$ )}

These two additions are said to be what God intended: an apocalyptic revelation by God to his people, received by Mordecai. In Addition A, Mordecai saw two dragons and a small river. $\mathrm{He}$ reflected on it but did not know what it meant. The answer is given in Addition F. Mordecai and Haman represented the two ¿рákovтєs ('dragons'), symbols of pride and selfishness. They fought and destroyed everything and, in the process, harmed themselves. Esther represented the river, symbolising strength (Moore 1984:248). She was able to enter the king's palace and use her power to save her nation.

\section{Edict against the Jews and its reversal (B and E)}

This is one of the most important parts of the Additions. These sections appear to be official documents. Written in quiet, eloquent Greek, they are potentially deadly letters of execution and reveal just how sombre the crisis was. The first is the letter of execution of the Jews. The second is the fruit of the presence of Esther in the royal palace. Haman was accused and condemned to death but, thanks to Esther, the Jews were praised, protected and even allowed to celebrate the Purim Festival. Thanks to Esther, the Jews, as the underdogs, would eventually triumph. Again, what we have here is a reversal of roles (Spangenberg 2004:805), this time caused by the intervention of a woman. It is here that Ben Sira's discourse on women proves to be outdated: the birth of this little girl - Esther - was not in vain.

\section{Susanna (in the Additions to Daniel)}

Like Judith and Esther, Susanna is a book about a Jewish woman from the same period. Like the other books, it is a story about a crisis but - this time - within the Jewish community. The heroine of the story is a woman called Susanna, who was accused by two Jewish elders of adultery with a young man. The real reason for the charge was that Susanna had refused to have intercourse with them, which made the accusation a form of retaliation. These elders were appointed judges. The text is quite explicit negatively so - about their characters:

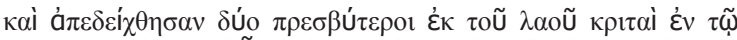

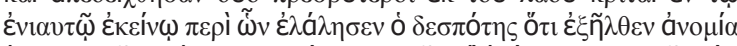

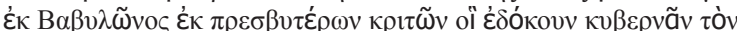
$\lambda \alpha o ́ v$

('In that year, two elders from the nation were appointed, people of whom the Lord said: Lawlessness came from Babylon from the elders who were judges, who were supposed to rule the nation.')

(Susanna 5)

Susanna was trialled, found guilty and led away to be killed, upon which she prayed a sincere prayer. Then God intervened. He resurrected the Holy Spirit, which resided in a young man called Daniel and who subsequently took over the defence of Susanna. Daniel was personified as a 'good judge', who followed certain procedures before reaching a verdict. He eventually ruled in favour of Susanna after questioning the elders separately, as a good judge would do. A fitting title for this story could be 'bad judge, good judge'.

However, since the story is also about a gender issue, it is important to see how its message is a reversal of Ben Sira's discourse about women. Ben Sira saw women as a threat to men. Here, men were a threat to women: they harassed them sexually and even lied about it!

To summarise: Ben Sira was biased against women. As a wisdom teacher - like the authors of Proverbs and Ecclesiastes - he chose to take a mainly negative view of women. He considered women to be dangerous and useless whores. This must have caused a certain discomfort in Jewish circles; new literature with female protagonists revealed these tensions and demonstrated that some Jews dreamed of a new status for women. Jews had an abundance of positive male and female traditions that they could use to create contra-narratives and they utilised these to break down negative perceptions of women.

Like David, the widow Judith was depicted as a general commander of a national army. She delivered the nation when no man had the courage to do likewise. Like Joseph, Esther was portrayed as a Jew in a foreign king's palace; through the actions of Esther, a letter of execution against the Jews was reversed. Susanna resisted sexual advances and the subsequent blackmail 
of men. Something similar happened to Joseph in Potiphar's house. Susanna was depicted as a moral pillar within the Jewish community.

Thus, in the period directly before the $\mathrm{CE}$, women were deemed worthy of both moral integrity and even of rescuing the Jewish nation in difficult circumstances. They were equal to men in all respects - and even surpassed men in some areas. Jesus Ben Sira's negative view was reversed: he was subtly criticised and corrected by Judith, the Additions to Esther and Susanna.

It is pity that this era is so neglected and even regarded with so much suspicion, because we can learn so much from it. By writing these books, the Jews were, in fact, campaigning for women's equality. The following section shows how this history of the Jews might have been utilised as allusions to various passages in the New Testament.

\section{POINT OF DEPARTURE CONCERNING NEW TESTAMENT LITERATURE}

A few points should be clarified before possible allusions in the New Testament from the Old Testament Apocrypha are sought. The first is to acknowledge the conflict that existed between Judaism and early Christianity. Contrary to popular belief, is it not the Christians but the Jews who were the dominant force (Dunn 2006:343). Ironically, these two adversaries claimed the same set of books to prove their authenticity. It is only natural that Christianity, being more recent, applied the same literary techniques as Judaism to gain superiority. The most common literary technique, as stated in the secion entitled 'Problem Statement', was the reinterpretation of the scriptures. It was therefore through reinterpretation that Christianity tried to establish itself as the authentic 'people of God' and, at the same time, to create a new set of books (Burkett 2002:105). With this in mind, possible allusions are explored in the following section.

\section{POSSIBLE ALLUSION BY PAUL TO THE OLD TESTAMENT APOCRYPHA ON WOMEN}

Paul dealt with the equality of people on account of their faith in Christ Jesus. A good example of this can be found in Galatians:

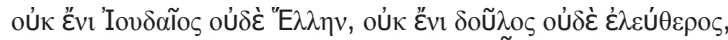

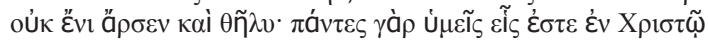
'Iๆбoũ

('There is no Jew or Greek, no slave or freeman, no man or woman. You are all one in Christ Jesus.')

(Galatians 3:28)

Here, Paul made a statement on the abolition of three different social divisions because of unity in Christ: there were no more Greeks or Jews, slaves or freemen, men or women. In Judith, we also have examples of the abolishment of the same social divisions. There were no more Jews or Ammonites (Achior was circumcised and thereby accepted as a Jew), slaves or freemen (Judith's slave was freed), men or women (Judith rose to the level of a man ('David' by killing Holofernes). Might it be possible that Judith influenced Paul? Why should this example of Judaism be ignored?

\section{POSSIBLE ALLUSION BY JESUS CHRIST TO THE OLD TESTAMENT APOCRYPHA ON WOMEN}

Research into the historical Jesus has shown that Jesus was on friendly terms with the outcasts of society (Barton 2001:162-163). This affection included not just women in general but also a 'certain type' of woman, namely women with bad reputations. In Luke 7:36 to 50, Jesus sided with such a woman against Simon the Pharisee. He stated, in Luke 7:47 - to the frustration of his

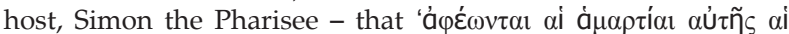
$\pi \mathrm{o} \lambda \lambda \alpha \mathrm{l}^{\prime}$ ('her sins, which were a lot, are forgiven').

In this context of Jesus having compassion for women of bad reputation, one passage stands out, namely John 7:53 to 8:11.
This deals with the woman who was caught in the act of adultery. The passage is not part of the oldest manuscripts of the New Testament. It did, in fact, surface for the first time in manuscripts from the seventh century (Metzger 1975:219-220). The reason for this might be its radical stance on adultery. However, regardless of its textual tradition, there might be a resemblance between this story and Susanna in the Additions to Daniel. In both cases, we have a woman accused by men of adultery. In both cases, there is a judge. In Susanna, it is Daniel. In the case of John's Gospel, the judge is Jesus, who was also resurrected from the dead. In both cases, we have a verdict. In the Susanna story, the woman is eventually acquitted by the sheer genius of Daniel; subsequently, the accusers - the men - are killed. In John's Gospel, the woman is found guilty by the geniality of Jesus as well as the accusers; the woman is not, however, stoned to death, as prescribed by the Law of Moses, and everybody is free to leave. Susanna might have been the impetus for the John 7:53 to 8:11 text. The latter would then be an allusion to the first. The purpose of the John pericope would, in such case, be to show that Jesus was an even better judge than Daniel. Jesus' judgement entailed not only forgiveness for one person but also introspection for the accusers, which was an advantage to Christianity over Judaism. Table 1 shows the points of resemblance and difference.

\section{SWING TOWARDS BEN SIRA IN THE LATTER DISPUTED PAULINE EPISTLES}

It seems as if a swing back towards Jesus Ben Sira and his associates occurred in the latter disputed Pauline epistles. In 1 Timothy 2:9 to 15 and 5:2 to 16, women are again placed in a bad light and all types of restrictive measures are placed on them:

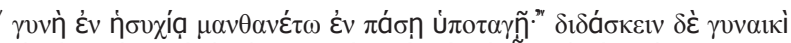

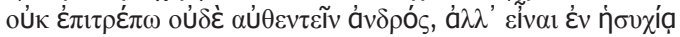

('A woman should be taught in silence in all subordination. I do not permit women to teach or to govern over a man, but she should be quiet!')

(1 Timothy 2:11-12)

and

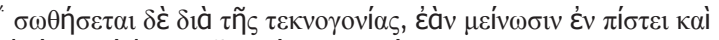
á $\gamma$ ám

('But she will be saved by bearing children, if they remain in faith and love and holiness with piety!')

(1 Timothy 2:15)

On widows:

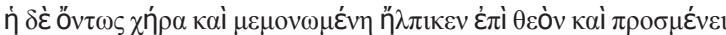

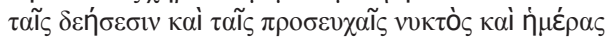

('And she who is a widow and was left alone, hope on God and remain in petitions and prayers day and night!')

(1 Timothy 5:5)

Women had to keep quiet - as Sira stated - and were not allowed to teach; they were furthermore saved by bearing children! Widows had to do almost nothing and had to place their hope in God and prayer. Again, there is no direct evidence within the Old Testament Apocrypha but resemblance to the writings of

TABLE 1

The points of resemblance and difference between Daniel and John

\begin{tabular}{|c|c|c|}
\hline & SUSANNA: DN 13 & JN 7:53-8:11 \\
\hline Accused & Susanna & Unnamed woman \\
\hline Charge & Adultery & Adultery \\
\hline Judge & Daniel & Jesus \\
\hline Verdict & Not guilty & $\begin{array}{l}\text { Guilty, both the accused as well as } \\
\text { the accusers }\end{array}$ \\
\hline Result & Death to the accusers & Life to the woman and the accusers \\
\hline Net result & Retribution for one person & $\begin{array}{l}\text { Forgiveness for the woman and } \\
\text { introspection for the accusers }\end{array}$ \\
\hline
\end{tabular}


Ben Sira is clearly there. This surely constitutes a swing back towards a more conservative view on women.

\section{CONCLUSION}

The acknowledgement by Charlesworth that the New Testament is a product of a long historical and linguistic process has widened the scope of possible pre-texts substantially. Development within literary science and philosophy in terms of intertextuality and contra-narratives has made the search for pre-texts all the more exciting. It has been argued that Judith, the Additions to Esther and Susanna - books with female protagonists - emerged as a result of Ben Sira's negative view on women. This positive development was followed by Paul and Jesus Christ. At least two New Testament texts have been shown to be possible allusions to texts from the Old Testament Apocrypha. It has been argued, however, that in the latter disputed Pauline texts, there was a swing back towards the suppressive views on women of Jesus Ben Sira and his associates. The treasure of the Old Testament Apocrypha and its relationship to the New Testament need further exploration. The New Testament might be more indebted to the time frame $196 \mathrm{BCE}$ to the CE that we currently acknowledge. This calls for further investigation.

\section{REFERENCES}

Aune, A.E., 1989, The New Testament in its literary environment, The Westminster Press, Philadelphia.

Barton, S.C., 2001, Life together. Family, sexuality and community in the New Testament and today, T \& T Clark, Edinburgh.

Boda, M.J., Falk, D.K. \& Werline, R.A., 2006, Seeking the favor of God, Society of Biblical Literature, Atlanta.

Bruce, F.F., 1979, New Testament interpretation, Paternoster Press, Exeter.

Burkett, D., 2002, An introduction to the New Testament and the origins of Christianity, Cambridge University Press, Cambridge.

Charlesworth, J.H., 1985, The Old Testament pseudepigrapha and the New Testament, Cambridge University Press, Cambridge.

Collins, J.J., 1999, Invitation to the Apocrypha, Eerdmans, Grand Rapids.

Day, L., 1995, Three faces of a queen. Characterization in the Books of Esther, Sheffield Academic Press, Sheffield.

DeSilva, D.A., 2002, Introducing the Apocrypha, Baker Academic, Grand Rapids.

Di Lella Alexander, A., 1996, 'Women in the wisdom of Ben Sira and the Book of Judith. A study in contrasts and reversals', Virginia Seminary Journal 61, 39-52.

Dunn, J.D.G., 2006, The partings of the ways, SCM Press, London.

Epston, D. \& White, M., 1990, Narrative means to therapeutic ends, W.W. Norton \& Company, New York.

Fox, M.V., 1991, Character and ideology in the Book of Esther, Eerdmans, Grand Rapids.

Gruen, E.S., 1998, Heritage and Hellenism. The reinvention of Jewish tradition, University of California Press, Berkeley.

Harvey, C.D., 2003, Finding morality in the Diaspora. Moral ambiguity and transformed morality in the Books of Esther, Walter de Gruyter, Berlin.

Jordaan, P.J., 2006, 'Text, ideology and body in the Additions to Esther', Ekklesiastikos Pharos 88(17), 138-151.

Jordaan, P.J. \& Kanonge, D.M., 2006, 'Women (whores?), wars and wisdom', Ekklesiastikos Pharos 88(17), 68-78.

Kaiser, O., 2004, The Old Testament Apocrypha. An introduction, Hendrickson, Peabody.

Kottsieper, I., 1998, Das Buch Baruch der Brief des Jeremia zu Esther und Daniel, Vandenhoek \& Ruprecht, Göttingen.

Malherbe, A.J., 1986, Moral exhortation, a Greco-Roman sourcebook, The Westminster Press, Philadelphia.

Metzger, B.M., 1975, A textual commentary on the Greek New Testament, United Bible Societies, New York.

Moore, C.A., 1985, Daniel, Esther and Jeremiah The Additions, Doubleday, New York.

Mussner, F., 1967, Der Jakobusbrief, Herder, Freiburg.
Nickelsburg, G.W.E., 2005, Jewish literature between the Bible and the Mishnah, Fortress Press, Minneapolis.

Sarup, M., 1989, An introductory guide to post-structuralism and postmodernism, University of Georgia Press, Georgia.

Spangenberg, I.J.J., 2004, 'Joodse narratiewe in die Persiese tydvak: Ideologie?', HTS Teologiese Studies/Theological Studies 60(3), 791-813.

Trenchard, W.C., 1982, Ben Sira's view of women, Scholars Press, Chico.

Van Maanen, D., 1954, Het Boek Ruth, Bosch \& Keuring N.V., Baarn 